\title{
Class in a Multicultural Age: \\ Organization of American Historians Meeting
}

\author{
Charles Carlson \\ Stanford University
}

The April 1997 conference of the Organization of American Historians $(\mathrm{OAH})$ in San Francisco was thematically centered on "the meanings of citizenship." Despite the relatively expansive body of work by labor historians which has directly or indirectly addressed this theme over the years, there were relatively few sessions that dealt with labor or working-class history. I attended several of these panels but was most intrigued by a session on "Recasting Citizenship: The Uses of Class in a Multicultural Age." The papers and discussion at this panel incorporated both controversial issues within the field of labor history and issues pertinent to future labor and social scholarship-not to mention movements.

The panelists represented an impressive cross-section of scholars who have written against the grain of a field once centered exclusively on the white, male, organized working class. Elizabeth Faue, Robin Kelley, James Horton, Alice Kessler-Harris, and David Roediger have each in their own way challenged and expanded our understanding of class in relation to community, race, and gender. Their observations and comments at this session both sharpened that challenge and generally moved from a scholarly focus to a broader context of academic and social activism. Specifically, the issue of the uses of class in a multicultural age was approached as a methodological problem, as a political problem within the academy, and as a challenge to building a new and vital labor movement.

Elizabeth Faue (Wayne State University) opened the session with the question, "What do we do with class in terms of citizenship?" She identified a fundamental problem in this relationship by noting that although notions of citizenship have historically been rooted in work and work identities, class and citizenship have been articulated in languages which are both reinforcing and competing. She continued with the contention that, generally, class has been excluded from the national discourse on the meaning of citizenship, with a few notable exceptions: the rise of the American Federation of Labor in the 1920s, which brought to the forefront the idea of the respectable (white, male) citizen-worker; the labor movement of the 1930s led by the Congress of Industrial Organizations, through which class determined the scope of claims made on citizenship; and the era from 1979 to the present, in which class has come into competition with race and gender as a primary determiner of identity. In the current era, the relationship of class to citizenship and the state has remained unclear. 
If the popular conception of citizenship is a sense of belonging or owning a piece of the national cultural heritage, Faue asked, then how does class fit into national culture? And, in the United States, what exactly is a national culture? Faue's questions adhered to the conference theme and placed emphasis on the construction of identity, a theme which in various ways dominated the discussion that followed.

James Horton (George Washington University) explored race, class, and gender in the abolition discourse of free black communities before the Civil War. Horton's presentation focused on how free blacks used the language of masculinity to attack slavery and on the consequences of this activist discourse for the construction of gender within free black communities. He linked the rhetoric of manhood employed by free black males to aspects of the language of white middle-class republicanism and noted that African-American women both fully participated in the movement and also adopted the language of black masculinity to support the antislavery movement. For example, Maria Stewart, a free black woman, challenged "sons of Africa to, in the spirit of manhood, challenge white society and demand freedom and citizenship."

Horton claimed that black women suffered from the gendered assumptions embedded in appeals to black, republican manhood; women took on broadened public and private responsibilities in support of the movement but received no commensurate elevation of status in return. Their opportunities for agency increased, but the gendering of citizenship rights in purely masculine terms placed limitations on those opportunities. Horton also proposed that the abolition/liberation movement in free black communities before the Civil War was ultimately compromised by the use of a class-based, gendered language of resistance and contributed to reinforcing women's dependent status in free black communities.

Robin Kelley (New York University) also addressed the issue of the relationship between class and race in the construction of identity, but his presentation broadened the discussion into the politics of academia and the role of class and race in contemporary society. Kelley leveled an opening salvo against the "neo-Enlightenment, white-boy Left" argument that race and gender have marginalized class in current labor scholarship, proposing instead that the tendency toward academic specialization obscures the ability to identify class-based movements. He asked, rhetorically, "Does multiculturalism camouflage class?" And answered, "Perhaps"-but emphasized that class is an unstable marker of identity. Class mobility and class-based politics have made this a nation of "class suicide."

Kelley dismissed class as a useful concept by following with examples of immigrants with professional identities thrown into wage labor on arriving in the United States. He then discussed the tendency of AfricanAmerican struggles for citizenship to cast class and gender as potential Achilles' heels. But he resurrected class a few moments later: For instance, middle-class blacks call upon poor African-Americans to "valorize their 
particular race/citizenship identity." Kelley also criticized the tendency of some labor scholars to reify the materiality of class as a social relationship while treating race and gender purely in terms of social constructions. He pointed out that slavery and even criminal law are also material relations with a racial base.

In stripping away the insulation and diminishing the scholarly distance of the academy from social issues of class, race, and gender, Robin Kelley gave credence to Elizabeth Faue's contention that we are living in an era in which the language of class exists in competition with concepts of race and gender. Kelley, however, was not content with leaving the discussion in a state of suspension. He proposed that transformative change (both in the real world and inside the university) will only come through a rethinking of class in a multicultural context. He also cautioned that the wisdom of resurrecting citizenship as movement strategy - a subject approached earlier by Faue and subsequently by Alice Kessler-Harris-needs to be considered cautiously. He closed by saying that those of us who still believe in the ideas presented in the lyrics of the Internationale, "We shall be all," need to take those lyrics seriously before effective social movements can be rebuilt.

Rutgers University's Alice Kessler-Harris picked up on Kelley's discussions of class within the academy and the building of social/labor movements in society at large. She opened by addressing the question of the relevance of class as a transformative agent in a multicultural age, offering a redefinition of class to fit the new scholarship in US labor history. Beginning with E. P. Thompson's definition, she agreed that "class is a process," of which gender, race, and religion are constitutive and mutually relational. Class, she continued, is socially constructed but objectively produced in relations of production. She insisted that class is relevant and useful but that it needs to be employed "far more capaciously" than it has been up to this time and that we must always recognize that is unstable.

Kessler-Harris then turned to citizenship and proposed that we also approach it as a process, not an abstract ideal. She noted that citizenship endows groups with both positive and negative rights which both enable and restrain, endowing groups with power in the process. "Class counts because citizenship is produced in struggles over power," she stated. Her case study on this point involved the 1930s "right-to-work" movement (a topic explored in depth by Eileen Boris and Patricia Cooper in another session) and the competing, gendered claims to citizenship and the right to work by working-class men and middle-class women.

The right-to-work movement's claims were engendered in masculine terms formulated in the context of the family wage and free labor. Ultimately, women abandoned the right-to-work issue for protective labor legislation relating to women only and lost all claims on citizenship related to work. Kessler-Harris also provided a cautionary tale regarding the use of citizenship and "rights" in movement building. 
David Roediger (University of Minnesota) closed the discussion and, in many ways, pulled together the dual focus on the scholarly applications and political applications of class in multicultural society. He started by talking about a recent USA Today article that had stated that the majority of organized workers in the United States were no longer either white or male, and he illustrated this fact by recounting a vacation trip to Las Vegas during which the Hotel and Restaurant Employees Union (HERE), a union in which women and people of color form a large majority of the rank and file, were conducting an organizing drive. He asked, "Can we return to class as an organizing tool?" He cautioned that in "getting back to class, we have to realize what we're getting back to." Using the work of Alexander Saxton on white workers in the western United States, he explored the pitfalls of using concepts of class based on the assumption that workers are white and male. Roediger concluded that, as labor historians, we have progressed in writing inclusive working-class histories but are also writing amidst a chorus of apprehension that labor history is in decline. Roediger rejected, in qualitative terms, the decline of labor history. $\mathrm{He}$ cautioned, however, that its acceptance in the broader field of US History should not be complacently presumed. The discussion that followed ranged broadly but clustered around competing historical interpretations of class, race, and gender and how multiculturalism fits into building a new labor movement.

The session on the uses of class in a multicultural age at the $\mathrm{OAH}$ conference generated many more questions than answers on its central issues. It did, however, reveal a vitality and a level of interest which reassured those of us who were concerned by the small number of labor and working-class history sessions at the conference and by the weak attendance at some of those sessions. This session's greatest value, perhaps, was in the consistent crossing of borders between class-as-an-analytical-tool and class-as-a-transformative-agent: Today, race, gender, and citizenship have tremendously complicated both applications.

\title{
A National Association for Working-Class History
}

\author{
James R. Barrett
}

University of Illinois at Urbana-Champaign

Several developments have converged recently to produce the first serious discussion of establishing a national organization of scholars, activists, and others concerned with advancing the study of working-class history in the United States. Among these are the "crisis" in labor history, however real 